\title{
Social segregation and lethal police violence in the city of São Paulo, Brazil (2014-2015)
}

\author{
Segregação social e a violência policial letal na cidade de São Paulo, \\ Brasil (2014-2015)
}

Marcelo Ryngelblum (https://orcid.org/0000-0003-4737-6366) ${ }^{1}$

Maria Fernanda Tourinho Peres (https://orcid.org/0000-0002-7049-905X) ${ }^{1}$

${ }^{1}$ Departamento de Medicina Preventiva, Faculdade de Medicina, Universidade de São Paulo. Av. Dr. Arnaldo $455,2^{\circ}$ andar, sala 2177 , Pacaembu. 01246-903 São Paulo SP Brasil. marceloryn@gmail.com

\begin{abstract}
We aimed to investigate how lethal police violence (LPV) in the City of São Paulo (CSP), Brazil, is associated with socioeconomic development when we consider the victims' place of residence and the locations of the fatal injuries. The spatial distribution of lethal police violence rate (LPVR) and its association with the human development index (HDI) was investigated using the Moran's I (Global and Bivariate Local). Between 2014 and 2015 we found 403 police victims in the Health database and 794 victims in the Security Department. We found a non-random spatial distribution of the LPV considering the victim's place of residence $(I=+0.12 ; p<0.001)$ and the locations where the fatal injuries were inflicted $(I=+0.07 ; p<0.001)$. We found a negative association between LPVR and the HDI of the place of residence $(I=-0.10 ; p<0.001)$ and a positive association between LPVR and the HDI of the locations of the fatal injuries $(I=+0.02 ; p<0.001)$. The results point to different dynamics of $L P V$ in CSP. High mortality clusters are found in areas with lower HDI, when considering the victim's address, and in areas with higher HDI, when considering the address of the violent events. $L P V$ impacts young blacks, poorly educated residents of outskirts informing us about patterns of social segregation.
\end{abstract}

Key words Legal intervention, Police, Spatial Analysis, Social segregation
Resumo Investigamos em que medida a violência policial letal (VPL) na cidade de São Paulo, Brasil, guarda relação com desenvolvimento socioeconômico, considerando os locais de residência das vítimas e os endereços dos eventos fatais. A distribuição espacial da taxa de violência policial letal (TVPL) e sua associação com o índice de desenvolvimento humano (IDH) foi investigada por meio do Moran's I (Global e o Local Bivariado). Entre 2014 e 2015 encontramos 403 vítimas da polícia no banco de dados da Saúde e 794 no da Segurança Pública. Constatamos uma distribuição não aleatória da TVPL considerando os locais de residência das vitimas $(I=+0,12 ; p<0,001)$ e os locais de encontro fatal com a polícia ( $I=+0,07$; $p<0,001)$. Encontramos uma associação negativa ( $I=-0,10 ; p<0,001)$ entre as TVPL e o IDH nos locais de residência e uma associação positiva entre as TVPL e o IDH nos endereços dos eventos fatais $(I=+0,02 ; p<0,001)$. Os resultados apontam para dinâmicas distintas da VPL na CSP. Clusters de alta mortalidade foram encontrados em áreas com menor IDH, quando consideramos o endereço das vitimas, e em áreas com maior IDH, quando consideramos o endereço dos eventos fatais. A VPL impacta jovens negros, com baixa escolaridade, vivendo nas periferias, nos informando dos padrões de segregação social.

Palavras-chave Intervenção legal, Polícia, Análise espacial, Segregação social 


\section{Introduction}

Since 1996, when the World Health Organization recognized Violence as a Global Public Health problem, there has been a growing understanding that there is a need for the phenomenon to be addressed from a public health perspective ${ }^{1}$. The impact of interpersonal violence on mortality is perceived through the large number of homicide deaths worldwide. In Brazil, much of it is related to the use of firearms and disproportionately impacts men, youth, black people and those living in peripheral areas of urban centers $\mathrm{s}^{2,3}$

In 2018, the American Public Health Association (APHA) approved the statement that violence perpetrated by law enforcement institutions needs to be tackled from a public health perspective, once these institutions can perpetuate physical, psychological, sexual and even negligent violence. In this context, tackle police violence (PV) is considered paramount to strengthen democracy and the health conditions of the population. This declaration stems from the recognition of the negative consequences of violent policing and its impacts on the most marginalized populations and the racial selectivity of public security apparatuses ${ }^{4}$. Since the police is one of the most visible faces of the State, the way it exercises authority does not simply reproduce inequalities, but may deepen them, reinforcing precarious models of citizenship ${ }^{5}$.

Several studies indicate that marginalized populations are disproportionally exposed to experiences of $\mathrm{PV}$, including people living with mental disorders ${ }^{6}$, LGBTQI+ population ${ }^{7}$, homeless $^{8}$, people with low income 9 , sex workers ${ }^{10}$, drug users ${ }^{11}$, and residents or visitors of police hyper-surveilled neighborhoods ${ }^{12}$.

Studies are consistent in demonstrating that homicide deaths are concentrated in areas with poorer socioeconomic conditions and of racial segregation ${ }^{13,14}$. Regarding violence perpetrated by the police, spatial distribution studies are rarer, which is partially explained by the difficulty to access information and poor quality of data ${ }^{15-17}$. In a study conducted in the USA ${ }^{18}$ higher rates of police-related deaths occurred in neighborhoods with the highest concentration of black and low-income residents, concluding that the contextual characteristics of a certain neighborhood are important to understand, prevent, and respond to lethal police violence (LPV).

Brazil is a profoundly unequal country with high levels of violence, a strong presence of organized crime groups in urban territories, and rec- ognized violent action by police forces ${ }^{19}$. In 2017, more than 65,600 homicides occurred in Brazil, 6,220 deaths were perpetrated by the police. In the State of São Paulo, in the same period, $20 \%$ of all homicides were caused by the police ${ }^{20}$. Brazil is one of the countries with largest number of cases of LPV in the world ${ }^{21}$.

Few studies, however, have sought to investigate the characteristics and spatial distribution of these deaths and their association with the victims' living conditions. The few studies carried out, analyzed the spatial dynamics either according to the locations where the fatal injuries were inflicted ${ }^{22,23}$, or to the victim's place of residence ${ }^{24}$, but no study sought to analyze the spatial dynamics of both sources of data which provide different information about the same occurrences.

It is possible to assume that there are differences in the spatial distribution of death, as well as in its association with socioeconomic conditions of urban areas, when we consider the victims' place of residence or the locations where the fatal injuries were inflicted. Our main hypothesis is that LPV impacts poor people in wealthy areas - as they are perceived as suspicious - and also in poor areas, where they live. Our analysis allows us to advance in understanding LPV not only in the CSP but globally, once we could not find any study considering spatial distribution of LPV according to both place of residence and the location where fatal injury were inflicted.

In this article our objective is investigate the association between Lethal Police Violence Rate (LPVR) socioeconomic development in the CSP when we consider the victims' place of residence and the locations where the fatal injuries were inflicted.

\section{Methods}

This study was conducted at the CSP, capital of the state of São Paulo and the largest city in Brazil with approximately 12 million inhabitants. According to the Atlas of Human Development of the United Nations Development Program (UNDP) Human Development Index (HDI) at the CSP in 2010 was 0.805, which makes São Paulo a city with a very high HDI. In 2017, according to official data from the Municipal Secretariat of Health, the CSP Homicide Mortality Rate was 9.1/100,000 inhabitants.

The CSP is internally divided into $1,593 \mathrm{Hu}-$ man Development Units (HDUs) and in this study, we will use the HDUs as unit of analysis. 
V. Furthermore, 2014 is the first year of an increasing trend in lethal police violence in the city of São Paulo, which is still growing.

The first official sources is: 1) Program for Improving Mortality Information (PROAIM) of the Health Department of the CSP, where data are recorded from the death certificate (DO), and the cause of death is classified following the 10th. edition of the International Classification of Diseases (ICD-10). A database of all cases classified under code Y35 (Legal Intervention) was obtained with the following information: age; home address; education; sex; race/skin color; date and time of death. The second official source is: 2) Public Security Secretary of the State of São Paulo, responsible for the consolidation of criminal records, which are registered in Police Reports. The Public Security classifies LPV as homicide resulting from police intervention. All incident reports registered were requested based on the law of access to information. The following information for each case were collected: sex; date of birth; race/skin color; and locations where the fatal injuries were inflicted.

The use of the two data sources allows spatial analysis to be carried out considering the victims' home address, available on death certificates, and the locations where the violent events occurred, available in the police records.

The resident population of the city of São Paulo was obtained from UNDP database in order to calculate the mortality rates per 100,000 inhabitants for each HDU. UNDP uses data from the Demographic Census conducted by IBGE in 2010. To characterize the degree of human development in the HDUs we used the HDI obtained from the UNPD Brazilian Atlas of Human Development. The HDI is an indicator composed of three dimensions of human development: health, education and income ${ }^{25}$.

This project was approved by the Ethics Committee of the University of São Paulo Medical School.

\section{Analysis}

Initially, we performed a descriptive analysis of the victims sociodemographic characteristics for each of the sources of information separately. For this analysis, we used Stata 12 software.

All the cases were geocoded via Google MyMaps website considering the addresses (victims place of residence and locations where the fatal injuries were inflicted). Through the MMQGIS plugin, in QGIS software, we counted the deaths in each HDU. We estimated the 2-year average LPVR per 100,000 inhabitants using the Spatial Empirical Bayesian Rate (SEBR) for each HDUs. For this, a neighbor matrix was created based on a second-order Queen contiguity. We chose to use SEBR smoothing given the rarity of the event and the great variability in terms of population in each HDU.

The existence of spatial clusters was investigated through the Global Moran's I and the Local Moran's I. To analyze the spatial correlation between the distribution of LPVR and the HDI, we conducted Local Bivariate Moran's I. Statistical significance for Moran's was tested with Monte Carlo Test with 999 permutation $(\mathrm{p}=0.001)$.

For spatial analysis, we used GeoDa software. Additionally, we used QGIS 2.18.23 software for map creation.

\section{Results}

Between 2014 and 2015 in the CSP we found 403 police victims in the Municipal Health database and 794 in the registry of the Public Security State Department. The difference between sources is almost twice, with an underreporting by Health Department. The sociodemographic profile of the victims of LPV in the CSP are in Table 1.

Victims of LPV are mostly young, black, and male. The lowest age found was 11 years old, and the average age in both sources is similar, around 23 years old. According to both sources, there is a predominance of men among deaths $(>99,5 \%)$. About $60 \%$ to $70 \%$ of the victims were black (black + brown). It is important to emphasize that only $37 \%$ of the population in the CSP is black according to the census. Finally, most victims $(72 \%)$ had little or no education (less than three years of formal education). It is noteworthy that $14 \%$ had no formal education at all and only $1.5 \%$ had eight years or more of schooling (with at least elementary school).

Out of the 403 deaths recorded in the Health database, 385 (95.5\%) had registered addresses. We were able to geocode $99.5 \%$ of the cases. The 
Table 1. Sociodemographic characterization of victims of LPV in the CSP according to data from the Municipal Health Secretary and the Public Security Secretary. São Paulo, 2014-2015.

\begin{tabular}{|c|c|c|}
\hline \multirow{2}{*}{$\begin{array}{l}\text { Sociodemographic } \\
\text { characterization }\end{array}$} & \multicolumn{2}{|c|}{ Data Source } \\
\hline & SMS-SP (Health) $(\mathrm{n}=403)$ & SSP-SP (Public Security) $(n=794)$ \\
\hline \multicolumn{3}{|r|}{ 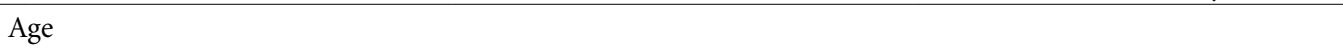 } \\
\hline Mean (sd); P50 (IQR) & $23.5(8.5) ; 21(\mathrm{IQR}=18-28)$ & $22.8(7) ; 21(\mathrm{IQR}=17-26)$ \\
\hline No Information & $9(2.23 \%)$ & $249(31 \%)$ \\
\hline \multicolumn{3}{|l|}{ Age } \\
\hline 0-14 years & $4(1 \%)$ & $4(0.7 \%)$ \\
\hline $15-19$ years & $162(41.1 \%)$ & $235(43.1 \%)$ \\
\hline $20-29$ years & $153(38.8 \%)$ & $221(40.5 \%)$ \\
\hline $30-39$ years & $52(13.2 \%)$ & $65(12 \%)$ \\
\hline $40-49$ years & $16(4.05 \%)$ & $18(3.4 \%)$ \\
\hline 50years + & $7(1.75 \%)$ & $2(0.4 \%)$ \\
\hline \multicolumn{3}{|l|}{ Sex } \\
\hline Men & $402(99.7 \%)$ & $721(99.5 \%)$ \\
\hline Women & $1(0.3 \%)$ & $3(0.5 \%)$ \\
\hline No Information & - & $70(9 \%)$ \\
\hline \multicolumn{3}{|l|}{ Race/Colour } \\
\hline White & $157(39.25 \%)$ & $223(30 \%)$ \\
\hline Black & $29(7.25 \%)$ & $84(11 \%)$ \\
\hline Brown & $214(53.5 \%)$ & $440(59 \%)$ \\
\hline No Information & $3(0.7 \%)$ & $47(6 \%)$ \\
\hline \multicolumn{3}{|l|}{ Educational status } \\
\hline No scholarity & $52(14 \%)$ & - \\
\hline $1-3$ & $214(57.7 \%)$ & - \\
\hline $4-7$ & $99(26.7 \%)$ & - \\
\hline $8-11$ & $2(0.5 \%)$ & - \\
\hline$>12$ & $4(1 \%)$ & - \\
\hline No information & $32(8 \%)$ & - \\
\hline
\end{tabular}

Source: Elaborated by the authors.

vast majority resided in the CSP ( $\mathrm{n}=361 ; 90 \%)$. The remaining $(\mathrm{n}=57 ; 10 \%)$ are deaths that occurred in CSP, but the victim resided in in another city, and therefore were excluded from our analysis.

Notably, when analyzing the distribution of deaths by the victim's place of residence, from the 1,593 HDUs of the city of São Paulo, 1,366 units $(85.75 \%)$ had no record of LPV. In the other $227(14.25 \%)$, there was at least one case, ranging from 1 to a maximum of 6 . The mean number of deaths by HDU in the CSP is 0.21 deaths $(\mathrm{sd}=0.63)$.

From the 794 cases registered by Public Security, considering the locations where the fatal injuries were inflicted, 717 (90.3\%) were geocoded using the address. Those police records who did not provide an address or had inaccurate records $(9,7 \%)$ were excluded from the analysis. In 1,210
HDU (76\%), there was no LPV. In the other 383 (24\%), there was at least one case, ranging from 1 to a maximum of 10 . The average number of deaths by HDU in the CSP was 0.45 deaths $(s d=1)$.

The LPVR, according to the victim's place of residence, ranged from 0 to 74.8 per 100,000 inhabitants. The average was 1.5/100,000 ( $\mathrm{sd}=2.4)$. Rates were divided into quartiles, named as: Low (less than $0.63 / 100,000)$, Intermediate (0.64$1.23 / 100,000)$, High (1.24-2/100,000) and Very high $(2.1-74 / 100,000)$.

The LPVR, according to the locations where the fatal injuries were inflicted, ranged from 0 to 137 per 100,000 inhabitants. The average was $3.5 / 100,000(\mathrm{sd}=4.2)$. Based on rates quartiles, we named categories as: Low (up to 2.0 deaths $/ 100,000)$, Intermediate (2.06$3.1 / 100,000)$, High (3.16-4.5/100,000) and Very high (4.5-137/ 100,000). 
In Figure 1 we present the LPVR distribution according to the victim's place of residence (1a) and the locations where the fatal injuries were inflicted (1b). Besides the mortality rates, in Figure $1 c$, we present a map of the distribution of the HDI by the HDU.

There is a complementarity between the maps, which together help to understand the urban dynamics related to mortality due to LPV in the CSP. According to the Health data (Figure 1a), which considers the regions of the victims' residence, the highest rates (fourth quartile) are mainly located at the edges of the city, in peripheral regions, such as the East and North HDUs. At the Central region and towards the beginning of the West Zone, areas with better socioeconom-
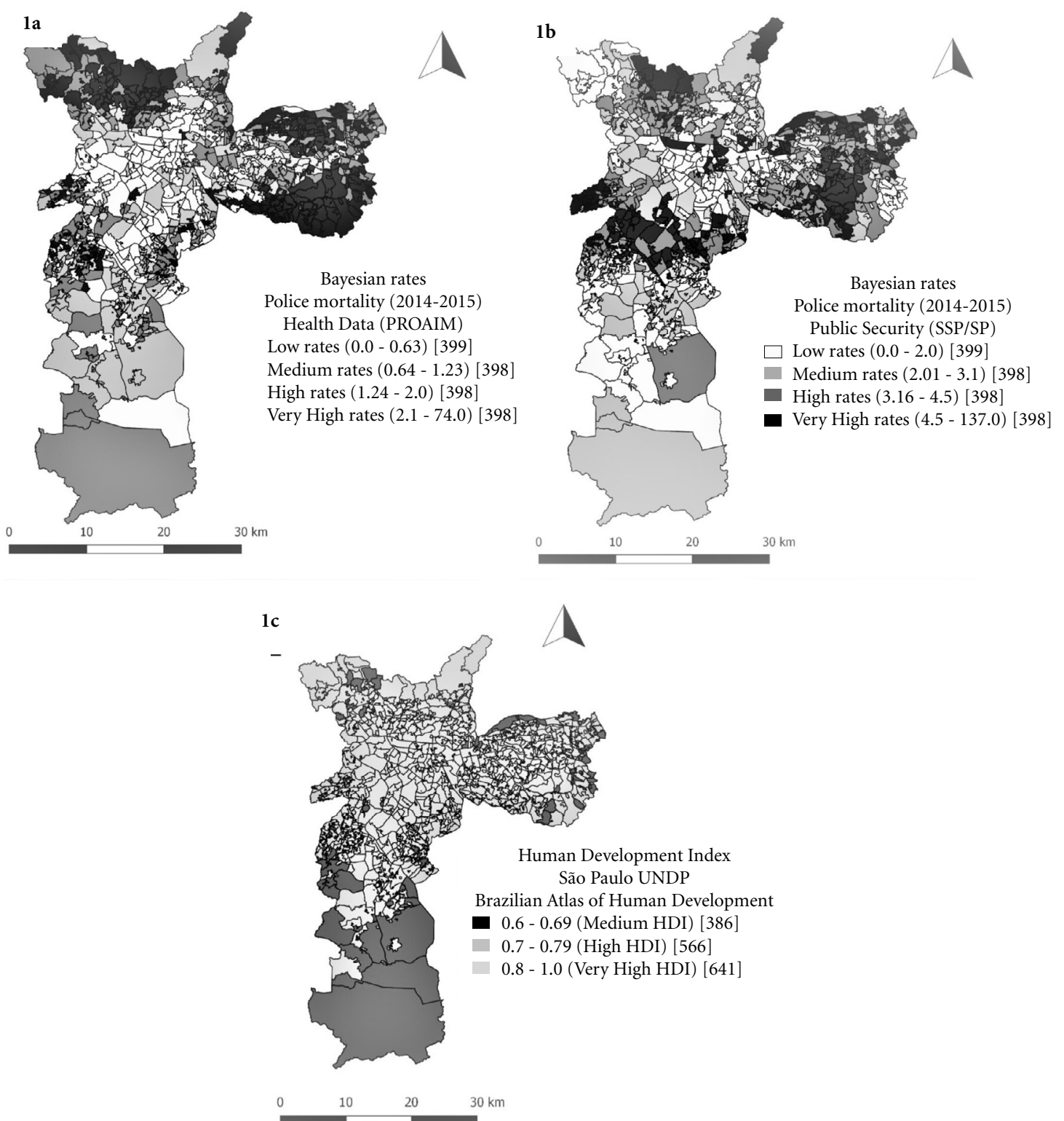

Figure 1. Spatial distribution of LPVR (100,000 inhabitants) in the CSP considering the victims' place of residence (1.a), the locations where the fatal injuries were inflicted (1.b), and spatial distribution of HDI by HDU (1.c). Sao Paulo, $2014-2015$. 
ic conditions, HDUs present mainly low (first quartile) and moderate (second quartile) rates.

According (Figure 1b), which is based on the locations where the fatal injuries were inflicted, the distribution of the mortality rates show a more diffuse and less pronounced pattern. We see high and very high rates in more affluent areas of the city: in and around the Center, as well as in the West zone. The eastern HDUs form a kind of "mortality belt", with rates ranging from moderate (second quartile) to very high (fourth quartile). High and very high rates are also found at the North, the south and west HDUs.

We can see an overlap between the HDU with high mortality rates, considering the places of living of the victims (Figure 1a), and the places with the worst socioeconomic indicators in the CSP (Figure 1c), evidencing the direction of State violence to more deprived areas at the periphery of the city, mainly in North and East region.

The Global Moran's I show a positive spatial correlation in the distribution of deaths considering both victim's place of residence $(\mathrm{I}=+0.12$; $\mathrm{p}=0.001)$ and the locations where the fatal injuries were inflicted $(\mathrm{I}=+0.07 ; \mathrm{p}=0.001)$. Despite exhibiting a low correlation magnitude, both values indicate the existence of spatial dependence of police lethality in the urban space of the CSP. We can see in Figure 2 the Global Moran's I scatter plot ( $1 \mathrm{a}$ e $1 \mathrm{~b}$ ) that shows us a positive linear fit through the point cloud that informs us about of patterns of spatial segregation.

Figure 3 shows the clustering of HDUs, with five distinct autocorrelation patterns identified. Of particular interest are the High-High pattern clusters with high mortality rates within the HDU and in surrounding neighborhoods, and the Low-Low pattern clusters with low mortality rates in the HDU and in surrounding neighborhoods.

When we consider the victim's place of residence (Figure 3a), low mortality clusters predominate in the Expanded Center of the city, mainly towards the West and South Zone. High mortality clusters are prominent in the East and North of the city. When considering the locations where the fatal injuries were inflicted (Figure $3 b$ ), High-High clusters are more distributed throughout the city, being present in all regions (North, South, Eastern and Western), except the Center. Low-mortality clusters are spread across the city, without a pronounced spatial pattern.

\section{Association between LPVR and the HDI}

The spatial correlation between LPVR and the HDI is presented in Figure 4. We found spatial correlation, whether considering the distribution of deaths by the victims' place of residence, or by the locations where the fatal injuries were inflicted. The direction of the correlation, however, are inverted. Based on Health data (home address) we found a negative correlation between LPVR and HDI $(\mathrm{I}=-0.10 ; \mathrm{p}<0.001)$ indicating higher mortality rates in areas with low HDI. On the other hand, based on the SSP data (locations where the fatal injuries were inflicted) we found a positive correlation $(\mathrm{I}=+0.02 ; \mathrm{p}<0.001)$, which indicates higher mortality in areas with better socioeconomic indicators.

In addition, Figure 4 shows the geographical distribution of spatial clusters for the association between HDI and the LPVR. Considering the locations where the fatal injuries were inflicted (Figure $4 \mathrm{~b}$ ), the HDUs with high mortality rates and high HDI are mostly in the expanded center and the boundaries between the center and the periphery, especially in the northern and southern regions of the municipality. When we consider the distribution according to the victims' place of residence (Figure 4a) we did not find clusters of high mortality in this same region. On the Figure $4 \mathrm{~b}$ low Mortality Rates and Low HDI clusters are concentrated in the peripheral regions of the East, North and South. In these same regions, on Figure 4a, are concentrated high mortality clusters. We can see, on Figure 4a, the HDU that concentrate police violence, mainly in the eastern region, deep South and North.

The scatterplot of the Bivariate Moran can be seen in Figure 2 (Scatter plot 2a and 2b) that show us the correlations of PLVR and HDI in the HDU and nearby areas. In scatter plot $2 \mathrm{a}$ we see a negative slope, and in the scatter plot $2 b$, we see a positive slope, but with values that report very low-intensity phenomena.

\section{Discussion}

Our results reinforce the evidence of racial and social bias on LPV as well as the existence of spatial clusters with high mortality. Additionally, our data corroborates the evidence of an uneven distribution of LPV, affecting differently those with a vulnerable social background. Most victims of police brutality are black, young, poorly educated. Besides, spatial analysis demonstrates that 

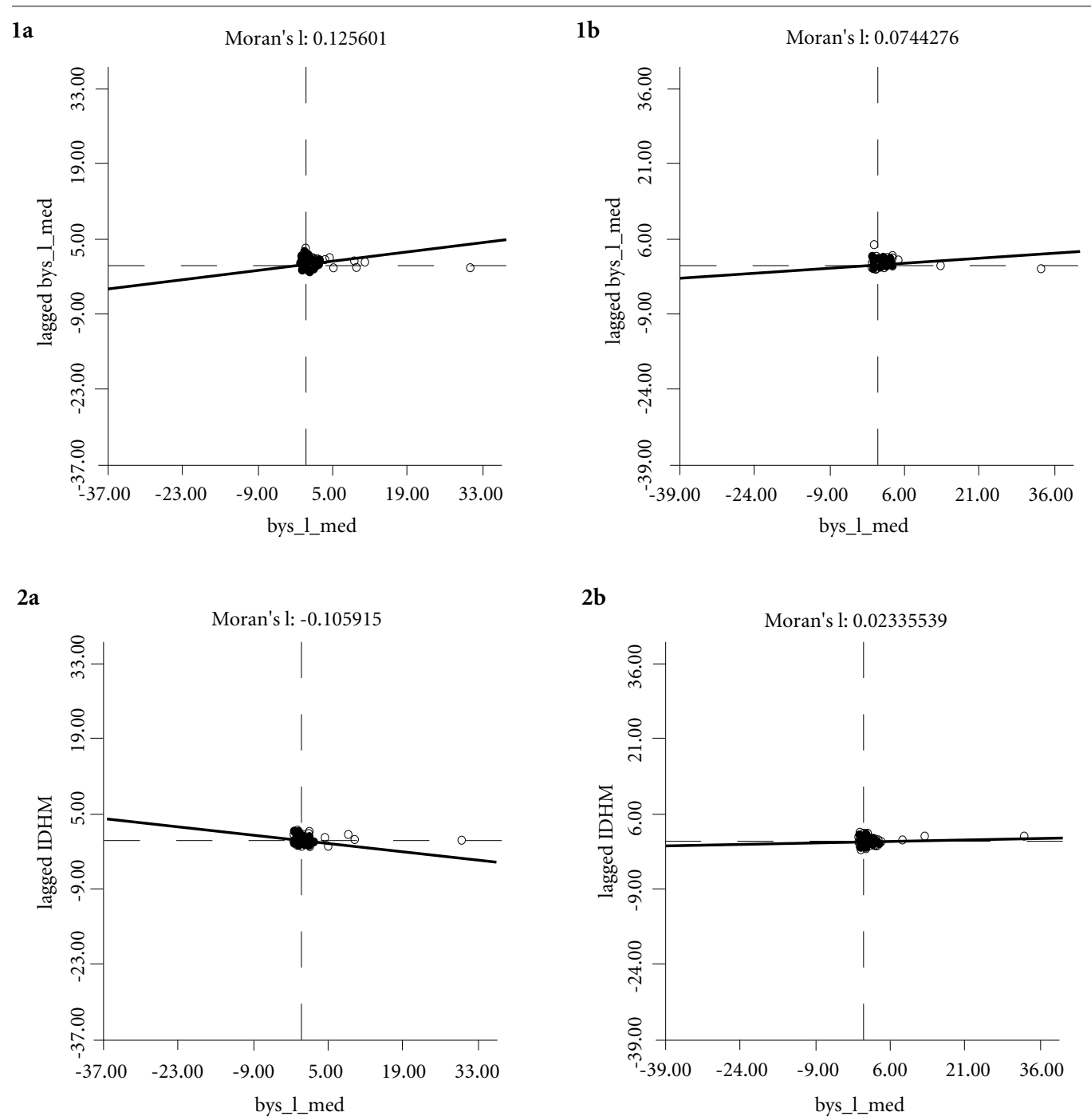

Figure 2. Global Moran's I Scatterplot and Bivariate Moran's I Scatterplot considering the victims' place of residence (1a and 2a), and the locations where the fatal injuries were inflicted (1b and 2b). São Paulo, 2014-2015.

Source: Elaborated by the authors.

victims of LPV live in deprived areas, while lethal confrontation focuses mainly on affluent areas of the city. The spatial analysis made it possible to identify distinct urban dynamics from LPV.

By working with two data sources, it was possible to observe that there are two complementary patterns of spatial distribution of police killings in the CSP. The first is through targeting social groups living in specific districts of the city, mainly the urban peripheries marked by the worst socioeconomic indicators and a negative correlation between mortality rates and the HDI. The second pattern, when we consider places of fatal encounters with the police, shows the pres- ence of violence both in peripheral districts, with the worse socioeconomic indicators, as in Center and near the Center districts, which have higher HDI. In this case, the correlation between mortality rates and the HDI is positive. Our results corroborate that of other authors, showing that PV mainly affects those in a weaker social posi$\operatorname{tion}^{3,6-12,15,17,18,26-32}$.

To better understand how differences are displayed, it is necessary to consider aspects related to police distribution and performance in the CSP. Police distribution and the repression it exercises in the CSP are closely linked with social hierarchies and power structures ${ }^{5,29}$. Popula- 


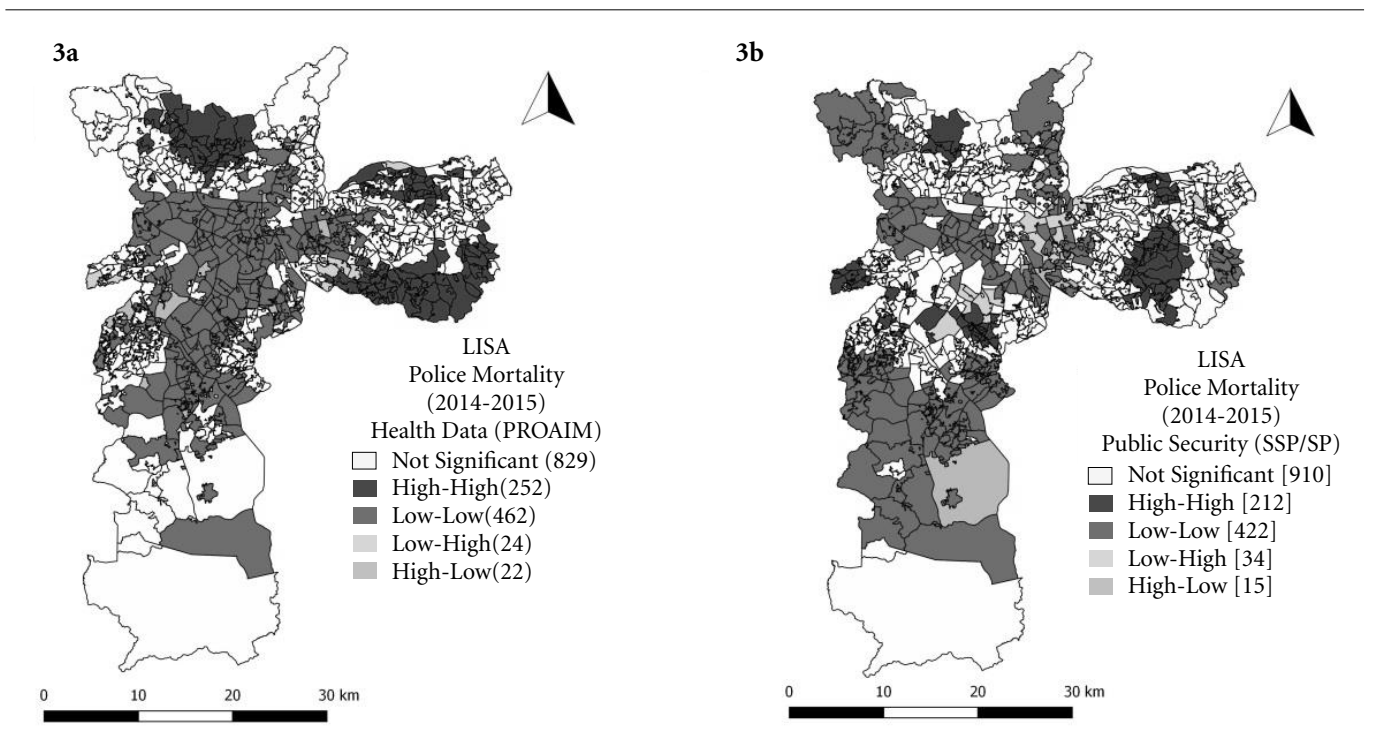

Figure 3. Moran Univariate Local Index (LISA) for the distribution of mortality from LPVR. São Paulo, 20142015.
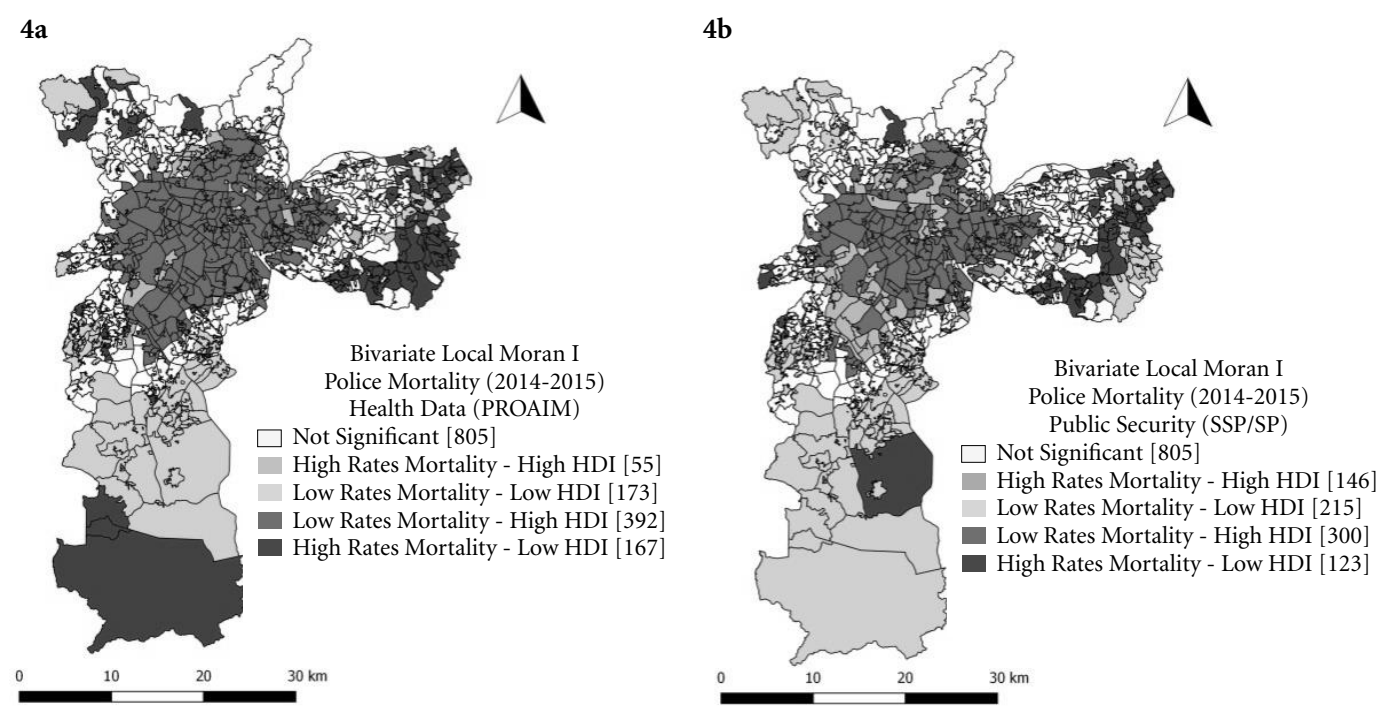

Figure 4. Moran Bivariate Location for the association LPVR and HDI. São Paulo, 2014-2015.

Source: City Hall of São Paulo, Municipal Department of Urbanism and Licensing (SMUL). Elaborated by the authors.

tion groups that have greater social prestige and economic power claim greater police presence in their neighborhoods and greater repression against socially disadvantaged inhabitants. According to Gonzalez ${ }^{5}$, the unequal distribution of safety occurs through two different manners:
The first would be the demands for repression, by citizens with higher social status, against those who are marginalized (by race/color, social class or spatial status). The second happens through the legitimation and prioritization of the population claims by the Public Security agents. Both 
legitimation and prioritization are based on the position and status of those who claim. This means that the Security Forces respond more to security and controlling demands from citizen groups with higher social status. These demands target marginalized groups of citizens living in vulnerable areas but also circulating in more affluent regions of the city where they could be perceived as dangerous, becoming vulnerable to LPV $^{29}$. Although we know that social hierarchies are closely related to LPV, we cannot discard other explanations for this pattern, that need to be further investigated.

The identification of different clusters of high mortality, when considering the address of residence and the occurrence of lethal conflicts, suggests the existence of social and racial segregation processes. This picture seems to contribute to racial discrimination by the State, when we consider the racial profile of the victims, supporting the evidence of the institutional racism of the police force. Different studies, from various countries, points to the racial bias in PV and LPV ${ }^{12,18,20,33,34}$. State-sanctioned violence, such as $\mathrm{PV}$ is one of the pathways that connect institutional racism and health ${ }^{33}$. Police killings in the city of São Paulo is part of an exclusion and segregation mechanism operated by the State that connect racism to social inequalities ${ }^{31}$.

The recognition of $\mathrm{PV}$ as a public health problem is recent. The many effects of PV on health are widely recognized and include physical, mental and moral consequences that may persist over time ${ }^{12-16,26-28}$. PV affects the health of the population and individuals, generates distrust and undermines the confidence in public institutions and policies ${ }^{4,15}$.

Although the social and health impact of PV is recognized ${ }^{4}$, its systematic study remains a challenge in different countries, including Brazil, due to the lack of reliable data ${ }^{20,35-37}$. To deal with this limitation, researchers are using alternative databases that aim at strengthening the validity of the given data, showing a better picture of the problem. In our paper two official sources were used: one reporting vital statistics (Health Department) and the other reporting criminal records (Public Security Department).

Even though some differences between the figures provided by distinct sources are expected, our data show a non-negligible underreporting of police killing by health authorities $(n=403)$, when compared to police records $(\mathrm{n}=794)$. Although Public Security reports more cases, its data is often incomplete regarding the sociode- mographic characteristics of the victims. Despite the underreporting, the health information system presents excellent quality considering the completeness of victims' sociodemographic information.

There are few studies on LPV in Brazil that use data from the health sector. This scarcity is explained by the underreporting of these deaths. A study ${ }^{35}$ in Salvador, Bahia, showed that deaths by Legal Intervention (Y35) are often classified as death by aggression (X85-Y09). The authors point out the existence of resistance, by forensic doctors, to use the category Y35 due to possible legal consequences. Also, the lack of articulation and an insufficient exchange of information between health departments and the police can make it difficult the correct classification of external causes death. In such cases, it is essential to clarify the circumstances of the death, through the regular access to police reports, and the building of formal and systematic flows for sharing information.

The acknowledgment of distinct problems affecting the quality of the official data suggests that efforts to make the two databases compatible would result in substantial gains for both. Linkage experiments with police, health, and media databases have been conducted ${ }^{36,37}$. These enabled a deeper understanding of the topic and improved the quality of information.

Analyzing and making public the data on LPV is necessary since it can be used as a tool to control police activity enabling better decision-making, with gains for the society as a whole, including improvements in the health of the population.

It should be stated that every effort to strengthen the quality and to guarantee access to information is a way to deepen the discussion on access to rights, contributing to social control and to improve the quality of the democracy. This is of special interest considering the growing of far-right political movements in different countries, including Brazil.

\section{Strengthens and limitations}

Our study has some strengths and limitations. As far as we know, it is the first study on the spatial distribution of LPV which analyzes data from two different official sources, making it possible to consider the spatial distribution of victims' homes and those of the violent confrontations. Most of the studies about the spatial distribution of LPV, from a public health per- 
spective, are from high-income countries with low violence and police killings rates. Research on LPV, in countries with a high number of cases and high social inequalities, such as Brazil, adds a valuable contribution to the knowledge about the topic. Our results reinforce the evidence of racial and social bias on LPV, as well as the existence of spatial clusters with high rates. Additionally, our data corroborate the evidence of an uneven distribution of LPV, affecting differently those with a vulnerable social background.

Even though our study has many strengths, some limitations should be taken into consideration when interpreting the results. As mentioned, the health information system underreports death derived from police intervention (ICD-10) when compared to criminal records. As a result, spatial analysis based on Health data that consider victims' residence could be biased. It is not possible to know if the results would be the same if all the cases were included in the analysis, once it is not possible to know the living address of those missing from the Health agency records. Data from Public Security lacks a non-negligible amount of information on some key variables such as age, and other sociodemographic indicators. We are not able to know how it affects the results of the descriptive analysis of victims' characteristics. To overcome both these issues, the linkage of health and criminal data would be necessary and is under construction. Additional analysis will be made, soon.

Another limitation is that our Analysis was based on crude mortality rates. We should also highlight that, when working with a rare event and with very small geographic units (HDU), LPVR can suffer great variability. We used Bayesian smoothing to work around this limitation.

As for HDU population, we used information from the 2010 Census, while LPV data were from the years of 2014 and 2015. Population estimates for HDU are not available for more recent years. The small time interval makes it unlikely that substantial changes have occurred to the extent of influencing the magnitude of the LPVR. The aggregations of census tracts, in the HDU, respect the limit of a minimum 400 households per unit. Although they were delimited considering contiguity, in some cases the criterion of spatial contiguity may not have been respected to guarantee the minimum of 400 households with homogeneous socioeconomic characteristic ${ }^{38}$. This can influence spatial patterns and subestimate the magnitude of spatial correlations. Another limitation, with a possible impact on spatial analysis, is that we did not perform a sample verification in geocoded addresses, but we had an excellent geocoding quality $(>90 \%)$.

\section{Conclusions}

Police forces have the prerogative of the legitimate use of force, and killing could be exceptionally justified in some specific circumstances. In Brazil the excessive number of cases, the profile of victims and the spatial distribution of deaths are clear signs that the use of lethal force is lacking exceptionality and its use can no more be considered legitimate.

Public Health and Public security information systems have flaws in LPV registry, such as underreporting and incompleteness, respectively. Efforts should be made to improve the quality of information about LPV in health system and criminal records, to reduce underreporting and lack of information. Regular sharing of information between police and health authorities and the linkage of database would generate a better diagnosis to foster the implementation of evidence-based policies.

Our results point to different dynamics of LPV in urban space in the MSP. High mortality clusters are found in areas with lower HDI, when considering the victims' home address, and in areas with higher HDI, when considering the address of the occurrence of the violent events. LPV disproportionately impacts young blacks, poorly educated residents of outskirts informing us about patterns of social segregation and inequality. 


\section{Collaborations}

The authors were involved in the conception of the study, analysis and interpretation of data, and writing the text. The authors have read and approved the final version of the manuscript.

\section{Funding}

Fundação de Amparo à Pesquisa do Estado de São Paulo (FAPESP), Coordenação de Aperfeiçoamento de Pessoal de Nível Superior (CAPES).

\section{References}

1. World Health Organization (WHO). World Report on violence and health. Geneva: WHO; 2002.

2. Reichenheim M, Souza E, Moraes C, Jorge MM, Silva C, Souza Minayo MC. Violence and injuries in Brazil: the effect, progress made, and challenges ahead. Lancet 2011; 377(9781):1962-1975.

3. Ribeiro E, Cano I. Vitimização letal e desigualdade no Brasil: evidências em nível municipal. Civitas 2016; 16(2):285.

4. American Public Health Association (APHA). Law enforcement Violence as a Public Health Issue. Washington, D.C: American Public Health Association; 2018.

5. González Y. "What citizens can see of the state": Police and the construction of democratic citizenship in Latin America. Theor Criminol 2017; 21(4):494-511.

6. Perry DM, Carter-Long L. The Ruderman White Paper on Media Coverage of Law Enforcement use of Force and Disability: a Media Study (2013-2015) and Overview. Ruderman Family Foundation; 2016.

7. Mallory C, Hasenbusch A, Sears B. Discrimination and Harassment by Law Enforcement Officers in the LGBT Community. Los Angeles: Williamn Institute; 2015.

8. Costa TGC. Condições do lugar: Relações entre saúde e ambiente para pessoas que usam crack no bairro da Luz, especificamente na região denominada cracolândia [dissertação]. São Paulo: Universidade de São Paulo; 2015.

9. Motley R, Joe S. Police Use of Force by Ethnicity, Sex, and Socioeconomic Class. J Soc Social Work Res 2018; 9(1):49-67.

10. Sherman S, Footer K, Illangasekare S, Clark E, Pearson E, Decker M. "What makes you think you have special privileges because you are a police officer?" A qualitative exploration of police's role in the risk environment of female sex workers. AIDS Care 2014; 27(4):473-480.

11. Cooper H, Moore L, Gruskin S, Krieger N. Characterizing Perceived Police Violence: Implications for Public Health. Am J Public Health 2004; 94(7):11091118.

12. Sewell A, Jefferson K. Collateral Damage: The Health Effects of Invasive Police Encounters in New York City. J Urban Health 2016; 93(S1):42-67.

13. Knopov A, Rothman E, Cronin SW, Franklin L, Cansever A, Potter F, Mesic A, Sharma A, Xuan Z, Siegel M, Hemenway D. The Role of Racial Residential Segregation in Black-White Disparities in Firearm Homicide at the State Level in the United States, 19912015. J Natl Med Assoc 2019; 111(1):62-75.

14. Siegel M, Sherman R, Li C, Knopov A. The Relationship between Racial Residential Segregation and Black-White Disparities in Fatal Police Shootings at the City Level, 2013-2017. J Natl Med Assoc 2019; 111(6):580-587.

15. Krieger N, Chen J, Waterman P, Kiang M, Feldman J. Police Killings and Police Deaths Are Public Health Data and Can Be Counted. PLoS Med 2015; 12(12):e1001915. 
16. Barber C, Azrael D, Cohen A, Miller M, Thymes D, Wang DE, Hemenway D. Homicides by Police: Comparing Counts From the National Violent Death Reporting System, Vital Statistics, and Supplementary Homicide Reports. Am J Public Health 2016; 106(5):922-927.

17. Loftin C, McDowall D, Xie M. Underreporting of Homicides by Police in the United States, 1976-2013. Homicide Stud 2017; 21(2):159-174.

18. Feldman J, Gruskin S, Coull B, Krieger N. Police-Related Deaths and Neighborhood Economic and Racial/ Ethnic Polarization, United States, 2015-2016. Am J Public Health 2019; 109(3):458-464.

19. Human Rights Watch (HRW). World Report 2019 [Internet]. 2019 [cite 2020 Jan 6]. Available from: https:// www.hrw.org/sites/default/files/world_report_download/hrw_world_report_2019.pdf.

20. Cerqueira D, Lima RS, Bueno S, Valencia LI, Hanashiro O, Machado PHG, Lima AS. Atlas da Violência 2017. Rio de Janeiro: IPEA, FBSP; 2017.

21. Fórum Brasileiro de Segurança Pública (FBSP). Anuário Brasileiro de Segurança Pública 2019 [Internet]. 2019 [cites 2020 Jan 6]. Available from: http://www.forumseguranca.org.br/wp-content/uploads/2019/10/ Anuario-2019-FINAL_21.10.19.pdf.

22. Instituto Sou da Paz. Análise dos Boletins de Ocorrência de Resistência Seguida de Morte Registrados na Cidade de São Paulo em 2012 [Internet]. 2015 [cited 2020 Jan 6]. Available from: http://soudapaz.org/oque-fazemos/conhecer/analises-e-estudos/analises-e -estatisticas/letalidade-policial/\#documentos-1.

23. Instituto Sou da Paz. Linha de Frente: vitimização e letalidade policial na cidade de São Paulo [Internet]. 2016 [cited 2020 Jan 6]. Available from: http://soudapaz.org/o-que-fazemos/conhecer/analises-e-estudos/analises-e-estatisticas/letalidade-policial/\#documentos-2.

24. Instituto Sou da Paz. Perfil das pessoas mortas na cidade de São Paulo por policiais em serviço (20022011) [Internet]. [cited 2020 Jan 6]. Available from: http://soudapaz.org/o-que-fazemos/conhecer/ analises-e-estudos/analises-e-estatisticas/letalidade-policial/?show=documentos $\# 2409$.

25. Programa das Nações Unidas para o Desenvolvimento (PNUD). Instituto de Pesquisa Econômica Aplicada (IPEA). Fundação João Pinheiro (FJP). Índice de Desenvolvimento Humano Municipal Brasileiro. Brasília: PNUD, IPEA, FJP; 2013.

26. Geller A, Fagan J, Tyler T, Link B. Aggressive Policing and the Mental Health of Young Urban Men. Am J Public Health 2014; 104(12):2321-2327.

27. DeVylder J, Cogburn C, Oh H, Anglin D, Smith ME, Sharpe T, Jun H-J, Schiffman J, Lukens E, Link B. Psychotic Experiences in the Context of Police Victimization: Data From the Survey of Police-Public Encounters. Schizophr Bull 2017; 43(5):993-1001.

28. DeVylder J, Frey J, Cogburn C, Wilcox HC, Sharpe TL, Oh HY, Nam B, Link BG. Elevated Prevalence of Suicide Attempts among Victims of Police Violence in the USA. J Urban Health 2017; 94(5):629-636.
29. Pinheiro PS. O passado não está morto: nem passado é ainda. In: Continuidade Autoritária e construção da democracia. São Paulo: Projeto Integrado de Pesquisa FAPESP, CNPQ, FFORD; 1997.

30. Sinhoretto J, Morais DS. Violência e racismo: novas faces de uma afinidade reiterada. Rev Estud Soc 2018; 64:15-26.

31. Vargas J, Amparo Alves J. Geographies of death: an intersectional analysis of police lethality and the racialized regimes of citizenship in São Paulo. Ethn Racial Stud 2010; 33(4):611-636.

32. Ruotti C, Almeida J, Regina F, Massa V, Peres M. A vulnerabilidade dos jovens à morte violenta: um estudo de caso no contexto dos "Crimes de Maio". Saude Soc 2014; 23(3):733-748.

33. Bailey Z, Krieger N, Agénor M, Graves J, Linos N, Bassett M. Structural racism and health inequities in the USA: evidence and interventions. Lancet 2017; 389(10077):1453-1463.

34. Bui A, Coates M, Matthay E. Years of life lost due to encounters with law enforcement in the USA, 20152016. J Epidemiol Community Health 2018; 72(8):715718.

35. Jesus T, Mota E. Fatores associados à subnotificação de causas violentas de óbito. Cad Saude Colet 2010; 18(3):361-370.

36. Lopes AS, Passos VMA, Souza MFM, Cascão AM. Melhoria da qualidade do registro da causa básica de morte por causas externas a partir do relacionamento de dados dos setores Saúde, Segurança Pública e imprensa, no estado do Rio de Janeiro, 2014. Epidemiol Serv Saude 2018; 27(4):e2018058.

37. Feldman J, Gruskin S, Coull B, Krieger N. Quantifying underreporting of law-enforcement-related deaths in United States vital statistics and news-media-based data sources: A capture-recapture analysis. PLoS Med 2017; 14(10):e1002399.

38. Martins C, Germano L, Rangel R. Metodologia das Unidades de desenvolvimento Humano da Região Metropolitana de Porto Alegre. Indic Econ FEE 2016; 43:91-108.

Article submitted 19/02/2020

Approved 23/07/2020

Final version submitted 25/07/2020

Chief editors: Romeu Gomes, Antônio Augusto Moura da Silva 